\begin{tabular}{lcl}
\hline 35$)$ & Jurnal Teknologi Kimia Unimal & $\begin{array}{l}\text { Jurnal } \\
\text { Teknologi } \\
\text { Kimia } \\
\text { Unimal }\end{array}$ \\
\hline http://ft.unimal.ic.id/teknik_kimia/jurnal & & \\
\hline
\end{tabular}

\title{
Pembuatan Pulp dari Batang Pisang
}

\author{
Syamsul Bahri ${ }^{1}$ \\ ${ }^{1}$ Jurusan Teknik Kimia, Fakultas Teknik, Universitas Malikussaleh \\ Laboratorium Teknik Kimia, Jl. Batam No. 2, Bukit Indah, Lhokseumawe 24353 \\ e-mail: amarul_bahari67@yahoo.com
}

\begin{abstract}
Abstrak
Penelitian ini dilakukan untuk menguji perolehan pulp dari batang pisang melalui proses soda. Bahan baku pulp terdiri atas selulosa, hemiselulosa, lignin dan ekstraktif. Pulp dapat dibuat dengan cara kimia, yaitu memasak bahan baku dengan menggunakan bahan kimia yang sesuai di dalam Reaktor. Batang pisang yang berukuran $1 \mathrm{~cm}$ sebanyak 10 gram dimasak dengan menvariasikan konsentrasi $\mathrm{NaOH}$ dan waktu pemasakan. Konsentrasi $\mathrm{NaOH}$ yang digunakan 0,5; 1; 1,5; 2 dan 2,5\% dengan waktu pemasakan 30; 60; 90; 120 dan 150 menit. Kondisi terbaik dari hasil penelitian diperoleh pulp $61.43 \%$, kandungan selulosa $83.3 \%$, dan kandungan lignin $2.97 \%$ pada waktu pemasakan 120 menit dan konsentrasi $\mathrm{NaOH} 2 \%$.
\end{abstract}

Kata kunci : batang pisang, pulp, selulosa, lignin.

\section{Pendahuluan}

Peningkatan kebutuhan kertas memberikan dampak yang kurang baik terhadap lingkungan karena sampai saat ini bahan baku utama pulp yang banyak digunakan adalah kayu. Akibatnya penebangan hutan menjadi semakin meluas. Selain itu proses pulping yang dilakukan menggunakan bahan kimia yang sukar untuk didegradasi secara alami. Salah satu alternatif untuk mengurangi efek yang kurang baik ini adalah dengan menggunakan bahan bukan nonkayu sebagai bahan baku pulp dan mencari proses yang lebih ramah terhadap lingkungan.

Laju perkembangan ekonomi dan industri sangat pesat memicu peningkatan kebutuhan akan kertas sebagai media informasi secara tertulis. Upaya untuk meminimalisasi biaya produksi yang disebabkan oleh kekurangan pasokan bahan baku kayu dan mahalnya harga kayu sudah lama dilakukan. Salah satunya adalah 
dengan mencari bahan baku alternatif dari bahan lain seperti batang pisang yang merupakan salah satu limbah biomasa yang terabaikan.

Pulp merupakan bubur kertas yang digunakan untuk pembuatan kertas. Pulp dapat dibuat dari bahan baku yang mengandung selulosa. Indonesia memiliki peluang yang sangat strategis dalam menghadapi era globalisasi kerja sama ekonomi. Disamping memiliki kesempatan untuk mengembangkan hasil pertanian agar dapat dipasarkan dalam kondisi segar, Indonesia juga berpeluang untuk mengembangkan industri pengolahan hasil-hasil pertanian menjadi produkproduk yang diminati pasar. Salah satu komoditas pertanian yang banyak dihasilkan dan memiliki pasar yang cukup luas adalah pisang.

Bahan baku dasar pembuatan pulp adalah selulosa dalam bentuk serat dan hampir semua tumbuhan yang mengandung selulosa dapat dipakai sebagai bahan baku pembuatan pulp. Bahan baku yang digunakan dapat berupa kayu jarum maupun kayu daun. Kayu jarum misalnya kayu pinus, kayu turi dan bambu, sedangkan yang termasuk kayu daun misalnya jerami, merang, batang pisang dan rumput-rumputan.

Batang pisang merupakan salah satu limbah (buangan) dari perkebunan pisang dapat juga dimanfaatkan sebagai bahan baku pembuatan pulp, karena mengandung selulosa. Selulosa terdapat pada semua tumbuhan, dari pohon bertingkat tinggi hingga organisme primitive seperti lumut dan gangang. Hampir semua tumbuhan yang mengandung selulosa dapat digunakan sebagai bahan baku pembuatan pulp (Fengel.D,1995).

Komponen lignoselulosa merupakan bagian terbesar yang menyusun tumbuh tumbuhan. Komponen ini terdiri dari selulosa, hemiselulosa, dan lignin. Lignoselulosa yang terdapat dalam limbah pertanian terdiri dari $40-60 \%$ selulosa, 20 - $30 \%$ hemiselulosa, dan 15 - $30 \%$ lignin. Susunan selulosa, hemiselulosa dan lignin dalam sel tanaman sangat kompleks. Hemiselulosa bersama lignin membalut serta menyatukan serat-serat selulosa. Wujud dari tiga dimensi lignin mengakibatkan struktur sel tanaman bersifat pasif dan kaku. Susunan yang kompleks tersebut mengakibatkan proses pemisahan komponenkomponen ini cukup rumit. 
Selulosa merupakan senyawa organik yang paling banyak melimpah di alam, karena struktur bahan seluruh dunia tumbuhan terdiri atas sebahagian besar selulosa. Suatu jaringan yang terdiri atas beberapa lapis serat selulosa adalah unsur penguat utama dinding sel tumbuhan. Didalam selulosa terdapat dalam bentuk serat-serat. Serat-serat selulosa mempunyai kekuatan mekanik yang tinggi. Selulosa merupakan suatu polimer yang berantai lurus yang terdiri dari unit-unit glukosa. Bobot molekul selulosa alamiah sukar diukur, dikarenakan degradasi yang terjadi selama isolasi. Panjang rantainya berbeda-beda dari jenis tumbuhan yang berbeda. Selulosa termasuk senyawa polisakarida yang mempunyai rumus empiris $\left(\mathrm{C}_{6} \mathrm{H}_{10} \mathrm{O}_{5}\right) \mathrm{n}$, dimana $\mathrm{n}$ berkisar dari 2000 sampai dengan 3000.

Nama hemiselulosa pertama kali diusulkan oleh Sehulzz pada tahun 1891 untuk menunjukkan polisakarida-polisakarida yang dapat disaring atau diekstraksi sebagai larutan alkali. Hemiselulosa menyusun sekitar 1/2 tumbuhan tahunan dan sekitar 1/3 tumbuhan semusim. Istilah hemiselulosa menunjukkan pada sejumlah besar polisakarida kompleks yang menyertai selulosa dalam dinding sel tumbuhan. Kebanyakan hemiselulosa adalah heteropolisakarida yang mengandung dua atau lebih monosakarida yang berlainan. Hemiselulosa mudah diekstraksi dari serat-serat dan kayu dengan larutan alkali. Hemiselulosa termasuk polisakarida yang terdapat bersama-sama dengan selulosa, bila dihidrolisa menghasilkan bermacam-macam sakarida seperti heksosa dan pentosa.

Lignin adalah polimer yang kompleks dengan berat molekul tinggi dan tersusun atas unit-unit fenil propan. Meskipun tersusun atas karbon, hidrogen dan oksida, tetapi lignin bukanlah suatu karbohidrat. Lignin terdapat di antara sel-sel dan didalam dinding sel. Di antara dinding sel lignin berfungsi sebagai pengikat untuk sel-sel secara bersama-sama.

Cara yang baik untuk mengisolasi lignin adalah dengan melarutkannya dalam pelarut yang cocok seperti dioksan. Lignin dengan hasil isolasi dengan cara ini lebih murni dan strukturnya relatif tidak berubah, hal ini disebabkan dioksan tidak bereaksi dengan lignin. Di dalam tumbuhtumbuhan, lignin merupakan bahan yang tidak berwarna. Jika lignin bersentuhan dengan adanya sinar matahari, maka lama-lama lignin cenderung menjadi kuning. 
Karenanya kertas koran yang terbuat dari serat-serat yang dipisahkan secara mekanis tanpa bahan kimia, tidak berumur panjang karena kecenderungannya menjadi kuning.

Pulp adalah hasil pemisahan serat dari bahan baku berserat (kayu maupun non kayu) melalui berbagai proses pembuatannya (mekanis, semikimia dan kimia). Pulp terdiri dari serat-serat (selulosa dan hemiselulosa) sebagai bahan baku kertas.

Kertas adalah bahan yang tipis dan rata, yang dihasilkan dengan kompresi serat yang berasal dari pulp. Serat yang digunakan biasanya adalah alami dan mengandung selulosa dan hemiselulosa. Kertas dikenal sebagai media utama untuk menulis, mencetak serta melukis dan banyak kegunaan lain yang dapat dilakukan dengan kertas misalnya kertas pembersih (tissue) yang digunakan untuk hidangan, kebersihan ataupun toilet. Sebagai bahan baku kertas, parameter yang penting dari pulp adalah kandungan selulosa dan kandungan lignin. Kandungan selulosa yang tinggi sangat diperlukan pada pembuatan kertas karena merupakan bahan dengan rantai yang panjang sehingga dengan kadar yang tinggi kertas yang dihasilkan akan kuat. Sedangkan kandungan lignin menunjukkan banyaknya lignin dalam pulp. Kandungan lignin yang tinggi dalam pulp tidak diinginkan, karena adanya lignin dapat menimbulkan warna coklat pada kertas. Adapun kualitas pulp kertas dapat ditunjukkan pada Tabel 1 dan Tabel 2.

Tabel 1 Kualitas pulp kertas

\begin{tabular}{|l|c|l|c|}
\hline \multicolumn{1}{|c|}{ Parameter } & Low yield & \multicolumn{1}{|c|}{ Medium yield } & High yield \\
\hline Bilangan Kappa & $14-20$ & $35-50$ & $60-110$ \\
\hline Kandungan lignin (\%) & $1,25-1,75$ & $3,12-4,45$ & $5,34-9,8$ \\
\hline Perolehan pulp (\%) & $35-45$ & $47-51$ & $49-53$ \\
\hline
\end{tabular}

Sumber : Nugroho dan Rusmanto, 1999 
Syamsul Bahri / Jurnal Teknologi Kimia Unimal 4 : 2 (November 2015) 36 - 50

Tabel 2 Kualitas Pulp yang Dihasilkan Industri Pulp Kimia

\begin{tabular}{|l|c|}
\hline \multicolumn{1}{|c|}{ Kualitas Pulp } & Industri Pulp Kimia \\
\hline Perolehan Pulp (\%) & $35-53$ \\
\hline Kandungan Selulosa (\%) & $>80 \%$ digunakan untuk pulp kertas \\
& $>90 \%$ digunakan untuk pulp rayon \\
\hline
\end{tabular}

Sumber : Marzuki 2005

Hampir semua tumbuhan yang mengandung selulosa dapat digunakan sebagai bahan baku pembuatan bubur kertas (pulp). Proses pembuatan pulp adalah proses pemisahan lignin untuk memperoleh selulosa dari bahan berserat. Oleh karena itu selulosa harus bersih dari lignin supaya kualitas kertas yang dihasilkan tidak berubah warna selama pemakaian. Proses pembuatan pulp dapat dibagi menjadi tiga proses yaitu proses mekanis, proses semi kimia, dan proses kimia.

Pembuatan pulp secara mekanis dilakukan tanpa menggunakan bahan kimia yaitu dengan cara menguraikan serat yang ada di dalam kayu secara paksa dengan menggunakan aksi mekanis. Bahan baku digiling dalam keadaan basah, serat-serat kayu akan terlepas, kemudian disaring sampai kehalusan tertentu untuk memperoleh bubur kertas (pulp). Dalam proses mekanis ini tidak dilakukan pemisahan komponen-komponen yang terdapat di dalam kayu sehingga pulp yang dihasilkan mempunyai kandungan bahan seperti semula. Keuntungan proses ini adalah biaya produksi yang rendah dan hasil yang tinggi karena pulp yang diperoleh sekitar $90 \%$ dari bahan semula. Kelemahannya adalah rendahnya mutu kertas yang dihasilkan, dimana kertas mudah sekali menjadi kuning dan kecoklatan karena kandungan ligninnya masih banyak.

Proses semi kimia adalah karena pada tahap awal pembuatan pulp digunakan bahan-bahan kimia sebagai pelunak bahan baku. Pelunakan dimaksudkan untuk memutuskan ikatan lignoselulosa dengan menghilangkan sebagian dari hemiselulosa dan lignin. Kemudian diperlakukan secara mekanis untuk memisahkan serat-seratnya. Disini pulp semi kimia masih mengandung lebih dari $25 \%$ lignin yang terdapat dalam kayu. Pulp yang diperoleh biasanya digunakan untuk membuat kertas pembungkus, kertas cetak dan papan kertas 
kayu. Jika konsentrasi bahan kimia semakin tinggi, maka penyerapan terhadap selulosa semakin naik dibandingkan dengan penyerapan terhadap lignin, yang dapat menghasilkan rendemen dan kekuatan rendah.

Proses pembuatan pulp secara kimia adalah proses pembuatan pulp yang menggunakan bahan kimia sebagai bahan utama untuk melarutkan bagian-bagian kayu yang tidak diinginkan. Rendemen pulp yang diperoleh dalam proses ini relatif rendah dibandingkan dengan proses mekanis dan semi kimia, yaitu antara $40-60 \%$, sehingga diperoleh produk selulosa yang lebih murni. Ada tiga macam proses pembuatan proses pembuatan pulp secara kimia yaitu proses soda, proses sulfat atau kraft, dan proses sulfit, masing-masing menggunakan larutan pemasak yang berbeda.

Keuntungan-keuntungan memakai proses kimia pada pembuatan pulp antara lain:

a. Dapat dilakukan pada semua jenis bahan baku.

b. Kekuatan pulp tinggi.

c. Pulp yang dihasilkan dapat digunakan untuk pembuatan rayon.

d. Kualitas kertas yang dihasilkan lebih tinggi.

Pada proses pemasakan, faktor-faktor yang berpengaruh antara lain jenis bahan baku, konsentrasi bahan kimia, suhu, waktu pemasakan, konsentrasi pelarut dan perbandingan cara pemasak terhadap bahan baku.

Pengenalan tentang anatomi kayu akan memberikan gambaran tentang bagian-bagian kayu yang berbeda sedangkan serat yang dinyatakan dalam panjang, tebal dinding dan sebagainya merupakan parameter yang berperan dalam kekuatan ikatan antar serat dalam lembaran kertas. Dengan demikian, jelas terlihat bahwa sifat dari serat yang digunakan akan menentukan kualitas kertasnya. Sehingga dalam pembuatan kertas, pengetahuan tentang bahan baku merupakan salah satu dasar yang perlu dikuasai.

Konsentrasi bahan kimia sangat penting dalam pembuatan pulp, karena berkaitan dengan reaksi antar bahan kimia pemasak dengan material kayu. Makin tinggi konsentrasi makin banyak material kayu yang bereaksi dengannya. Namun degradasi terhadap selulosa makin naik dibandingkan dengan penyerapan 
terhadap lignin. Hal semacam ini tidak diinginkan dalam proses pembuatan pulp. Namun konsentrasi tinggi tidak harus dihindari, hal itu diperlukan pada awal pemasakan untuk menetralisasi asam-asam yang terjadi. Untuk memperoleh pulp pada serat abaka dengan menggunakan bahan kimia, dengan cara dididihkan dalam NaOH 1-5 \% (S. M. Khopkar, 1990).

Waktu pemasakan sangat perlu diperhatikan, dimana waktu pemasakan dapat dikurangi beberapa saat dengan menaikkan suhu pemasakan. Biasanya pada waktu pemasakan tinggi rendemen dan kualitas pulp turun, sehingga pulp yang dihasilkan tidak bertahan lama. Vasquez, dkk (1994) menemukan bahwa semakin lama waktu reaksi maka semakin banyak lignin yang tersisihkan dari biomassa, sehingga kandungan lignin dalam pulp semakin berkurang, untuk waktu yang lebih lama kandungan lignin dalam pulp mempunyai kecendrungan untuk meningkat kembali. Waktu yang diperlukan untuk delignifikasi optimum adalah dalam rentang 60-120 menit, persen perolehan pulp dan selulosa tidak bertambah setelah 120 menit pemasakan.

Suhu pemasakan sangat penting dalam melakukan pemasakan, biasanya suhu pemasakan sangat ditentukan oleh jenis bahan baku yang digunakan. Suhu pemasakan berhubungan dengan laju reaksi. Delignifikasi dengan pelarut organik umumnya berlangsung pada suhu diatas $130{ }^{\circ} \mathrm{C}$. Dari persamaan Arhenius, menunjukkan bahwa semakin tinggi suhu reaksi maka konstanta laju delignifikasi akan semakin meningkat, sehingga pada suhu yang tinggi maka semakin banyak lignin yang dapat disisihkan dari biomassa. Selain meningkatnya laju delignifikasi pada suhu tinggi juga sebagian polisakarida akan terdegredasi (Vasquez dkk, 1994).

Konsentrasi pelarut sangat penting dalam pembuatan pulp, karena berkaitan dengan reaksi antara pelarut dengan biomassa. Semakin tinggi konsentrasi pelarut semakin banyak biomassa yang bereaksi dengannya. Namun degradasi terhadap selulosa semakin naik dibandingkan penyerangan terhadap lignin. Hal semacam ini tidak diinginkan dalam proses pembuatan pulp. Tetapi konsentrasi tinggi tidak harus dihindari, hal itu diperlukan pada awal pemasakan untuk menetralisasi asam-asam yang terjadi. 
Pelarut organik akan mampu melarutkan lignin dengan baik pada konsentrasi tertentu. Untuk pemasakan TKS menggunakan proses etanol dengan katalis $\mathrm{NaOH}$, konsentrasi etanol yang dipakai adalah $50 \%$ (Nugroho dan Rusmanto, 1999). Pada konsentrasi ini etanol dapat menjaga selulosa terdegradasi pada suatu perbandingan cairan padatan tertentu. Marzuki (2005) dalam penelitiannya terhadap sabut kelapa juga menggunakan konsentrasi etanol sebesar $50 \%$.

Perbandingan cairan pemasak terhadap bahan baku harus diketahui agar lignin dapat sempurna terlarut dalam cairan pemasak. Perbandingan yang terlalu besar akan menimbulkan ketidakhematan penggunaan cairan pemasak, sedangkan perbandingan yang terlalu kecil dapat menyebabkan pengendapan lignin. Untuk proses etanol- $\mathrm{NaOH}$ terhadap TKS digunakan perbandingan 20:1 (Nugroho dan Rusmanto, 1999), sedangkan Marzuki (2005) dalam penelitiannya terhadap sabut kelapa juga menggunakan perbandingan 20:1.

\section{Metode Penelitian}

\subsection{Bahan dan Alat}

Alat-alat yang digunakan pada penelitian ini, antara lain adalah auto klaf, saringan, beaker gelas, erlenmeyer, oven, timbangan, labu ukur, dan lain-lain. Adapun bahan yang digunakan pada penelitian ini, antara lain adalah batang pisang, $\mathrm{NaOH} 0,5 ; 1 ; 1,5 ; 2$; dan 2,5\%, etanol $99 \%, \mathrm{Na}_{2} \mathrm{~S}_{2} \mathrm{O}_{3} 2 \%$, dan lain-lain.

\subsection{Metode}

Variabel bebas dalam penelitian ini adalah konsentrasi $\mathrm{NaOH} 0,5 ; 1 ; 1,5 ; 2$; dan 2,5\% dan waktu pemasakan 30, 60, 90, 120 dan 150 menit. Variabel tetapnya adalah ukuran sampel, $1 \mathrm{~cm}$; suhu pemasakan, $130{ }^{\circ} \mathrm{C}$; berat batang pisang, 10 gram; tekanan, $17.5 \mathrm{Psi}$; dan rasio cairan/padatan, $6: 1$ (ml/gr). Variabel terikat dalam penelitian ini adalah kadar pulp, kadar selulosa, dan kadar lignin.

Bahan baku yang berupa batang pisang terlebih dahulu dicuci dan dikeringkan di bawah sinar matahari lalu dipotong-potong lebih kurang $1 \mathrm{~cm}$. Kemudian dimasukkan ke dalam oven dryer dengan suhu $105^{\circ} \mathrm{C}$ selama 24 jam 
agar memperoleh kandungan air yang seragam. Agar mencapai kondisi isotermal, autoklaf dioperasikan selama 45 menit.

Sepuluh gram batang pisang dimasukkan dalam beaker glass ditambahkan larutan $\mathrm{NaOH}(0,5 ; 1 ; 1,5 ; 2$ dan 2,5 \%) dengan perbandingan 6:1 lalu dimasukkan ke dalam autoklaf. Autoklaf dioperasikan pada temperatur dan tekanan yang telah ditetapkan yaitu $130{ }^{\circ} \mathrm{C}$ dan kemudian autoklaf dimatikan setelah operasi berlangsung sesuai dengan waktu yang divariasikan $(30,60,90$, 120 dan 150 menit). Batang pisang yang telah dimasak dikeluarkan dari autoklaf lalu didinginkan hingga suhu kamar. Residu dan filtrat dipisahkan dengan menggunakan kertas saring. Residu yang didapat kemudian dicuci dengan etanol dan dilanjutkan pencucian dengan air panas lalu dikeringkan dalam oven pada temperatur $105^{\circ} \mathrm{C}$ selama 60 menit. Padatan yang telah kering ditimbang (sebagai berat pulp kering), selanjutnya dilakukan analisa perolehan pulp, kadar selulosa dan lignin.

$$
\text { Perolehan Pulp }=\frac{\text { Berat pulp kering }}{\text { Berat batang pisang }} \times 100 \%
$$

\section{a. Analisa kadar selulosa (Metode SNI 14-0444-1989)}

1. Ditimbang sejumlah 3 gram pulp kering, lalu dimasukkan ke dalam beaker glass.

2. Pulp dibasahkan dengan $15 \mathrm{ml} \mathrm{NaOH} 17,5 \%$ dan diaduk selama 1 menit.

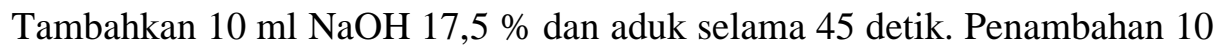
$\mathrm{ml} \mathrm{NaOH} 17,5 \%$ berikut dengan pengadukan 15 detik.

3. Campuran tersebut dibiarkan selama 3 menit.

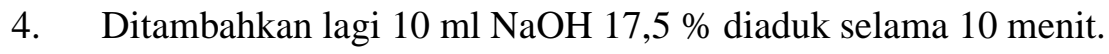

5. Dilakukan penambahan $3 \mathrm{x}$ dengan menggunakan $\mathrm{NaOH} 17.5 \%$ sebanyak $10 \mathrm{ml}$ setelah 2,$5 ; 5 ; 7,5$ menit. Dibiarkan selama 30 menit dalam keadaan tertutup.

6. Ditambahkan $100 \mathrm{ml}$ aquadest dan dibiarkan selama 30 menit.

7. Campuran tersebut kemudian disaring untuk diambil endapannya. 
8. Kemudian endapannya dicuci dengan menggunakan $50 \mathrm{ml}$ aquadest sebanyak 5 (lima) kali.

9. Ditambahkan $12.5 \mathrm{ml}$ asam asetat $2 \mathrm{~N}$ dan aduk selama 5 menit.

10. Kemudian dicuci dengan aquadest sampai bebas asam, uji dengan kertas lakmus.

11. Endapan dikeringkan dalam oven pada suhu $105{ }^{\circ} \mathrm{C}$ selama 60 menit, kemudian didinginkan dalam desikator dan ditimbang sampai beratnya konstan.

12. Kadar selulosa dihitung menurut rumus:

$$
\text { Kandungan Selulosa }=\frac{\text { Berat endapan selulosa }}{\text { Berat pulp kering }} \times 100 \%
$$

\section{b. Analisa Kadar Lignin (Metode SNI 14-0492-1989)}

1. Sebelum diuji, timbang 1 gram pulp kering dilarutkan terlebih dahulu dengan etanol $99 \%$ selama 8 jam, kemudian dicuci dengan air panas.

2. Sampel dipindahkan kegelas piala $100 \mathrm{ml}$, tambahkan asam sulfat $72 \%$ sebanyak $15 \mathrm{ml}$, penambahan dilakukan pelan-pelan dan dibiarkan selama $2-3$ menit.

3. Setelah dispersi sempurna, ditutup dengan kaca arloji dan dibiarkan selama 2 jam.

4. Sample tersebut lalu dipindahkan kegelas piala $500 \mathrm{ml}$ dan diencerkan dengan air sampai volume $575 \mathrm{ml}$.

5. Larutan dipanaskan sampai mendidih dan dibiarkan selama 4 jam.

6. Endapan dibiarkan mengendap sempurna dan dipindahkan ke kertas saring yang telah diketahui beratnya, endapan lignin dicuci dengan air panas sampai airnya jernih.

7. Kertas saring (berikut endapan) dikeringkan dalam oven pada suhu $105{ }^{\circ} \mathrm{C}$ selama 60 menit dan ditimbang sampai beratnya konstan.

8. Kadar lignin dalam pulp dihitung menurut rumus:

$$
\text { Kandungan Lignin }=\frac{\text { Berat endapan lignin }}{\text { Berat pulp kering di oven }} \times 100 \%
$$




\section{Hasil dan Diskusi}

Hasil penelitian dari persentase perolehan pulp, kandungan selulosa dan kandungan lignin diperoleh seperti pada Tabel 3, 4, dan 5. Perolehan pulp menunjukkan persentase antara berat murni pulp yang diperoleh setelah pemasakan terhadap berat sampel batang pisang. Kandungan selulosa adalah persentase berat murni $\alpha$-selulosa terhadap berat komponen total (selulosa, hemiselulosa dan lignin) dalam pulp. Sedangkan kandungan lignin menunjukkan persentase lignin yang terkandung di dalam pulp karena tidak terhidrolisis dengan reaksi delignifikasi pada waktu pemasakan dengan pelarut $\mathrm{NaOH}$.

Tabel 3 Perolehan pulp dari batang pisang

\begin{tabular}{|c|c|c|c|c|c|c|c|c|c|}
\hline \multicolumn{2}{|c|}{30 Menit } & \multicolumn{2}{|c|}{60 Menit } & \multicolumn{2}{c|}{90 Menit } & \multicolumn{2}{c|}{120 Menit } & \multicolumn{2}{c|}{150 Menit } \\
\hline $\begin{array}{c}\% \\
\mathrm{NaOH}\end{array}$ & Pulp & $\begin{array}{c}\% \\
\mathrm{NaOH}\end{array}$ & $\begin{array}{c}\% \\
\text { Pulp }\end{array}$ & $\begin{array}{c}\% \\
\mathrm{NaOH}\end{array}$ & $\begin{array}{c}\% \\
\text { Pulp }\end{array}$ & $\begin{array}{c}\% \\
\mathrm{NaOH}\end{array}$ & $\begin{array}{c}\% \\
\text { Pulp }\end{array}$ & $\begin{array}{c}\% \\
\mathrm{NaOH}\end{array}$ & Pulp \\
\hline 0,5 & 52,35 & 0,5 & 58,65 & 0,5 & 48,16 & 0,5 & 44.13 & 0,5 & 60,13 \\
\hline 1,0 & 54,95 & 1,0 & 56,67 & 1,0 & 46,14 & 1,0 & 41.02 & 1,0 & 60,35 \\
\hline 1,5 & 56,11 & 1,5 & 54,24 & 1,5 & 41,03 & 1,5 & 50.36 & 1,5 & 58,22 \\
\hline 2,0 & 57,11 & 2,0 & 52,58 & 2,0 & 38,30 & 2,0 & 61.43 & 2,0 & 52,30 \\
\hline 2,5 & 59,88 & 2,5 & 51,76 & 2,5 & 39,45 & 2,5 & 56.70 & 2,5 & 35,18 \\
\hline
\end{tabular}

Sumber : hasil penelitian 2010

Tabel 4 Perolehan selulosa dari batang pisang

\begin{tabular}{|c|c|c|c|c|c|c|c|c|c|}
\hline \multicolumn{2}{|c|}{30 Menit } & \multicolumn{2}{|c|}{60 Menit } & \multicolumn{2}{c|}{90 Menit } & \multicolumn{2}{c|}{120 Menit } & \multicolumn{2}{c|}{150 Menit } \\
\hline $\begin{array}{c}\% \\
\mathrm{NaO} \\
\mathrm{H}\end{array}$ & $\begin{array}{c}\% \\
\text { Selulos } \\
\mathrm{a}\end{array}$ & $\begin{array}{c}\% \\
\mathrm{NaO} \\
\mathrm{H}\end{array}$ & $\begin{array}{c}\text { Selulos } \\
\mathrm{a}\end{array}$ & $\begin{array}{c}\% \\
\mathrm{NaO} \\
\mathrm{H}\end{array}$ & $\begin{array}{c}\% \\
\text { Selulos } \\
\mathrm{a}\end{array}$ & $\begin{array}{c}\% \\
\mathrm{NaO} \\
\mathrm{H}\end{array}$ & $\begin{array}{c}\% \\
\text { Selulos } \\
\mathrm{a}\end{array}$ & $\begin{array}{c}\% \\
\mathrm{NaO} \\
\mathrm{H}\end{array}$ & $\begin{array}{c}\text { Selulos } \\
\mathrm{a}\end{array}$ \\
\hline 0,5 & 41.2 & 0,5 & 56.36 & 0,5 & 60.6 & 0,5 & 55.7 & 0,5 & 69.9 \\
\hline
\end{tabular}


Syamsul Bahri / Jurnal Teknologi Kimia Unimal 4 : 2 (November 2015) 36 - 50

\begin{tabular}{|c|r|r|r|r|r|r|r|r|r|}
\hline 1,0 & 43.53 & 1,0 & 58.23 & 1,0 & 54.1 & 1,0 & 52.43 & 1,0 & 71.63 \\
\hline 1,5 & 54.5 & 1,5 & 62.4 & 1,5 & 59.7 & 1,5 & 56.5 & 1,5 & 73 \\
\hline 2,0 & 56.8 & 2,0 & 63.8 & 2,0 & 61.4 & 2,0 & 39.63 & 2,0 & 68.9 \\
\hline 2,5 & 62.53 & 2,5 & 62.63 & 2,5 & 63.4 & 2,5 & 57.1 & 2,5 & 83.3 \\
\hline
\end{tabular}

Sumber : hasil penelitian 2010

Tabel 5 Perolehan lignin dari batang pisang

\begin{tabular}{|c|r|r|r|r|r|r|c|c|c|}
\hline \multicolumn{2}{|c|}{30 Menit } & \multicolumn{2}{|c|}{60 Menit } & \multicolumn{2}{c|}{90 Menit } & \multicolumn{2}{c|}{120 Menit } & \multicolumn{2}{c|}{150 Menit } \\
\hline $\begin{array}{c}\% \\
\mathrm{NaOH}\end{array}$ & $\begin{array}{c}\% \\
\text { Lignin }\end{array}$ & $\begin{array}{c}\% \\
\mathrm{NaOH}\end{array}$ & $\begin{array}{c}\% \\
\text { Lignin }\end{array}$ & $\begin{array}{c}\% \\
\mathrm{NaOH}\end{array}$ & $\begin{array}{c}\% \\
\text { Lignin }\end{array}$ & $\begin{array}{c}\% \\
\mathrm{NaOH}\end{array}$ & $\begin{array}{c}\% \\
\text { Lignin }\end{array}$ & $\begin{array}{c}\% \\
\mathrm{NaOH}\end{array}$ & $\begin{array}{c}\% \\
\text { Lignin }\end{array}$ \\
\hline 0,5 & 3.72 & 0,5 & 3.8 & 0,5 & 3.95 & 0,5 & 4.01 & 0,5 & 4.83 \\
\hline 1,0 & 4.01 & 1,0 & 4.14 & 1,0 & 4.13 & 1,0 & 4.31 & 1,0 & 4.89 \\
\hline 1,5 & 4.22 & 1,5 & 3.85 & 1,5 & 4.28 & 1,5 & 4.95 & 1,5 & 4.52 \\
\hline 2,0 & 4.45 & 2,0 & 4.53 & 2,0 & 5.31 & 2,0 & 6.01 & 2,0 & 4.98 \\
\hline 2,5 & 4.51 & 2,5 & 4.85 & 2,5 & 5.33 & 2,5 & 4.96 & 2,5 & 2.97 \\
\hline
\end{tabular}

Sumber : hasil penelitian 2010

\subsection{Pengaruh Konsentrasi NaOH dan Waktu Pemasakan terhadap \\ Perolehan Pulp}

Perolehan pulp yang dihasilkan berkisar antara $35.18 \%-61.43 \%$ bervariasi menurut kondisi operasi. Hasil yang diperoleh ini lebih baik dari pada range perolehan pulp yang dihasilkan industri pulp kimia dalam range $35 \%-63 \%$. Ini berarti pulp batang pisang dapat digunakan sebagai pulp kertas skala industri kimia karena sudah memenuhi standard kualitas pulp kertas menurut Nugroho dan Rusmanto.

Perolehan pulp tertinggi diperoleh pada waktu pemasakan 120 menit dengan konsentrasi $\mathrm{NaOH} 2 \%$, sebesar $61.43 \%$. Sedangkan perolehan pulp terendah diperoleh pada waktu pemasakan 150 menit dengan konsentrasi $\mathrm{NaOH}$ 
2,5\% sebesar $35.18 \%$. Perolehan pulp akan turun akibat derajat delignifikasi yang tinggi dan terjadi degradasi polisakarida dari sebagian selulosa dan hemiselulosa, tetapi diharapkan pada hasil penelitian ini, dengan meningkatnya derajat delignifikasi maka kandungan $\alpha$-selulosa di dalam pulp juga akan meningkat.

\subsection{Pengaruh Konsentrasi NaOH dan Waktu Pemasakan terhadap Kandungan Selulosa}

Dari penelitian yang telah dilakukan, bahwa suatu proses pemasakan menggunakan $\mathrm{NaOH}$ dengan peningkatan waktu pemasakan telah meningkatkan kandungan selulosa dalam pulp. Kandungan $\alpha$-selulosa yang diperoleh adalah berkisar antara $39.63 \%-83,3 \%$.

Kandungan selulosa tertinggi diperoleh pada konsentrasi $\mathrm{NaOH} 2.5 \%$ dengan waktu pemasakan 150 menit, yaitu sebesar 83,3\%. Sedangkan kandungan selulosa terendah diperoleh pada konsentrasi $\mathrm{NaOH} 2 \%$ dengan waktu pemasakan 120 menit, yaitu sebesar $39.63 \%$. Sesuai dengan kualitas pulp yang dihasilkan untuk industri kimia kandungan selulosa harus lebih besar dari $80 \%$, maka pada waktu pemasakan 150 menit dengan konsentrasi $\mathrm{NaOH} 2.5 \%$ telah menghasilkan kandungan selulosa yang sesuai dengan standar industri kimia.

\subsection{Pengaruh Konsentrasi NaOH dan Waktu Pemasakan terhadap Kandungan Lignin}

Dari penelitian yang telah dilakukan, suatu proses pemasakan dengan $\mathrm{NaOH}$ telah menurunkan kandungan lignin dalam pulp. Vasquez, dkk (1994) menemukan bahwa semakin lama waktu reaksi maka semakin banyak lignin yang tersisihkan dari biomassa, sehingga kandungan lignin dalam pulp semakin berkurang. Data komposisi kimia batang pisang menunjukkan bahwa sebelum pemasakan kandungan lignin dalam batang pisang sebesar $5 \%-10 \%$, sedangkan setelah proses pemasakan dilakukan kandungan lignin di dalam pulp menurun menjadi $2.97 \%$ - $6.01 \%$. Kandungan lignin tertinggi diperoleh pada waktu pemasakan 120 menit dengan konsentrasi $\mathrm{NaOH} 2 \%$, yaitu sebesar $6.01 \%$. Sedangkan perolehan lignin terendah diperoleh pada waktu pemasakan 150 menit 
dengan konsentrasi $\mathrm{NaOH} 2,5 \%$ yaitu sebesar $2.97 \%$. Kandungan lignin disini diharapkan sekecil mungkin, karena lignin dapat merusak kualitas pulp seperti warna pulp atau kertas akan menjadi kuning atau kecoklatan.

\section{Simpulan dan Saran}

\subsection{Kesimpulan}

Berdasarkan hasil penelitian dan pengolahan data, maka dapat diambil kesimpulan bahwa:

1. Kondisi operasi maksimum dari proses pembuatan pulp dari batang pisang adalah pada konsentrasi $\mathrm{NaOH} 2 \%$ dan waktu pemasakan 120 menit dengan hasilnya adalah perolehan pulp 61,43\%; kandungan $\alpha$-selulosa 83,3\%; dan kandungan lignin $2.97 \%$.

2. Pulp batang pisang yang dihasilkan dapat digunakan sebagai pulp kertas skala industri kimia karena sudah memenuhi standar, yaitu kandungan selulosa di atas $80 \%$.

\subsection{Saran}

Untuk penelitian selanjutnya sebaiknya dianalisis bilangan Kappa dan jenis batang pisang yang bervariasi.

\section{Daftar Pustaka}

Fengel, D. dan G. Wegener. Kayu, Kimia Ultrasturktur Reaksi-reaksi. UGM Press: Yogyakarta, 1995.

Marzuki, Fanni., 2005. Pembuatan Pulp Dari Sabut Kelapa Dengan Sistem Organosolv. Tugas Akhir Teknik Kimia, Universitas Malikussaleh.

Nugroho, Pralampitaning., dan Rusmanto. Pemilihan Pelarut Organik Etanol dan Asam Asetat Untuk Pembuatan Pulp Dari Tandan Kosong Sawit. 1999. 
Syamsul Bahri / Jurnal Teknologi Kimia Unimal 4 : 2 (November 2015) 36 - 50

S. M. Khopkar., Basic Concepts Of Analytical Chemistry, New Age International Publisher, UI-Press, Jakarta, 2003.

Vasquez, dkk., Amazonian Ethnobotanical Dictonary, CRC Press, Iquitos Peru, 1994. 